\title{
Effect of Strip Width on Proportion of Daily Light Reaching THE GROUND ${ }^{1}$
}

BY A. B. BERRY2

The proportion of daily light reaching the ground in clearcut strips can be governed with some precision by manipulating the width and orientation of the strips. If a strip is aligned north-south, the variability in mean daily light across it will be at a minimum on level terrain since each side will receive the same amount of direct insolation as the sun moves from east to west, a condition that cannot be met with any other alignment of the strip. Little factual information is available, however, on the effect of strip width on the percentage of daily light reaching the ground. To get preliminary data on this, the investigation described below was conducted at the Petawawa Forest Experiment Station (ca $46^{\circ} 00^{\prime} \mathrm{N}$. lat.) in July 1962.

In a dense plantation of 50-foot white spruce (Picea glauca (Moench) Voss), on level ground, a strip 200 feet long was laid out in a north-south direction and cut in three stages: width equal to $1 / 4$, to $1 / 2$, and to stand height itself. Before any cutting, light measurements were taken with Brockway exposure meters at three positions in the stand at 15 -minute intervals from 8.45 a.m. to $4.15 \mathrm{p} . \mathrm{m}$. and these were expressed as percentage of simultaneous measurements taken in a nearby open field.

The mean daily light based on averages of these readings was less than one per cent of that in the open. After each stage of strip widening, light measurements (timed as before) were taken across the strip about one chain from its north end, and simultaneous measurements were again made in the open. In the narrowest strip light was measured at the centre and the edges of the strip; in the two wider strips additional measurements were made at points midway between the centre and edges. (Light was measured on both sunny and cloudy days, since other local investigations indicate that clouds have little influence on mean values when these are expressed as a percentage of illumination in the open.)

Table 1 shows the average of all measurements across the strip as well as at the centre and edges. Mean daily light across the strip was remarkably

TABLE 1

EfFect of Strip Width and Position on Per Cent of Daily ILLUMINATION REACHING THE GROUND

\begin{tabular}{llll}
\hline \multicolumn{1}{c}{$\begin{array}{c}\text { Position on } \\
\text { the strip }\end{array}$} & \multicolumn{2}{c}{ Strip width in per cent of stand height } \\
\cline { 2 - 4 } & $\mathbf{2 5}$ & $\mathbf{5 0}$ & $\mathbf{1 0 0}$ \\
\hline Centre & 21 & 41 & 97 \\
Intermediate & - & 40 & $\mathbf{7 6}$ \\
Edge & 21 & 38 & 63 \\
Average across strip - & 21 & 40 & 74 \\
\hline
\end{tabular}

\footnotetext{
${ }^{1}$ Department of Forestry, Canada, Forest Research Branch Contribution No. 556

${ }^{2}$ Forestry Officer, Petawawa Forest Experiment Station, Chalk River, Ontario.
} 
uniform up to a strip width of half the stand height but its variability increased markedly for greater strip widths. Light at any point in a strip will vary considerably during the day because it will be in direct sunlight around noon and in varying degrees of shade for the balance of the day. Canopy density in the adjoining uncut stand would probably influence the percentage of mean daily light reaching the ground, particularly for narrow strips, but further tests would be required to determine its importance.

\section{Federal-Provinclal Conference On Forestry}

At this, the first meeting of Canada's eleven forest ministers, it was unanimously agreed that it is of the utmost urgency that Canadians be made fully aware of the social and economic values of the forest community, so crucial to Canada's continued development.

It was the opinion of the ministers that a renewable resource supporting our greatest single free enterprise industry consistently accounting for almost one-third of the total value of all Canada's exports, should receive, within the Constitutional division of responsibilities, a much greater degree of sound attention and development at all levels of Government.

It was agreed that the existing Federal-Provincial Forestry Agreements, covering inventory, reforestation, access roads, stand-improvement and forest fire protection, have been more or less satisfactory up to the present time. However, there is an urgent need for-(a) greater flexibility in the terms of the Agreement to permit wider provincial planning;-(b) an increase in the federal funds to be made available to the Provinces.

The Minister of Lands and Forests of Quebec made it clear that, while his Province is willing to consider renewal of the Federal-Provincial Forestry Agreement on the same general basis as before any such renewal is subject to the reservation, already expressed on several occasions by Prime Minister Lesage, regarding all federal-provincial agreements.

It is the opinion of the ministers that there is a great need for the co-ordination and increase of research efforts in the fields of forestry and forest products, economics, protection against fire, disease, and insects.

In the field of insecticides and biological control of harmful insects, the ministers recognize a special need and urgency for research.

More accurate inventory surveys of forest wealth are now urgently required in order to capitalize on possible future changes in world trading patterns.

It was also agreed that communication between those who do the forest research and those who use their results, must be greatly strengthened and improved between the federal, provincial and industrial organizations.

Recognizing that our forest industries are facing increasing and sophisticated competition in the markets of the world, the forest ministers agreed that forest programs of research and management must be strengthened in support of the industry and that at all times the programs must be related to the realities of economics. 